\title{
Using Interactive Web Tools in Environmental Planning to Improve Communication about Sustainable Development
}

\author{
Sebastian Krätzig ${ }^{1, *}$ and Bartlett Warren-Kretzschmar ${ }^{1,2}$ \\ 1 Institute of Environmental Planning, Leibniz University Hannover, Herrenhäuser Straße 2, \\ Hannover 30419, Germany \\ 2 Department of Landscape Architecture and Environmental Planning, Utah State University, \\ 4005 Old Main Hill, Logan, UT 84321, USA; E-Mail: barty.warren@usu.edu
}

* Author to whom correspondence should be addressed; E-Mail: kraetzig@umwelt.uni-hannover.de; Tel.: +49-511-762-9015; Fax: +49-511-762-3791.

Received: 25 November 2013; in revised form: 11 December 2013 / Accepted: 17 December 2013 / Published: 2 January 2014

\begin{abstract}
Public involvement in the landscape planning process is an essential opportunity to communicate the goals and objectives of a sustainable planning. However, it is also important to accommodate citizen's attitudes and perceptions of sustainability on a local or regional scale in the decision-making process. This involvement can be supported by interactive information, discussion, and learning opportunities. This article examines how communication in the context of environmental issues can be supported by modern web tools, social media, and new visualization approaches. Furthermore, the potential of social media to support communication about sustainability on a local scale and the prerequisites for its use in the planning process are discussed. Using a case study about citizens' response to the development of intensive livestock farming in rural setting, we examine what the perception of sustainability on local scale could mean for citizens. Another case study about interactive landscape planning illustrates how such tools can promote communication about environmental issues and local sustainability. Using a framework for the use of social media, we suggest different application levels of social media in participatory planning. Finally, the opportunities to support sustainable decisions with landscape visualization in environmental planning and decision-making issues are discussed.
\end{abstract}

Keywords: internet; environmental planning; participatory planning; communication; web tools; social media; visualization; local sustainability 


\section{Introduction}

The social protest and change in many countries over the past decades illustrates the growing expectations of citizens that governments provide improved opportunities for participation in decisions that affect the public (review "participatory revolution" [1,2]). In fact, governments and administrations have begun to communicate with the public about environmental issues in a more participatory, transparent, and collaborative manner [3,4]. The new administrative approaches that governments use to support transparency and open views on governmental task management, to improve the public knowledge base with information and data, and to promote feedback are called "Open Government". This more communicative and participatory style of administration aims to involve more people and to improve how well they are informed about issues in their jurisdiction. However, open government often fails to take full advantage of social media and interactive web tools in the communication between citizens and the government/administration as it lacks a comprehensive and targeted strategy [4]. Practitioners point out that the main prerequisites for using open government are not technical requirements, but rather cultural in nature, e.g., a more casual language and better acceptance of feedback. The planning discussion requires a communication culture that is more open and feedback orientated (ibid.).

The Internet provides opportunities to engage the public in "widening the knowledge base that informs planning decisions" [5]. For example, when the government and general public exchange information, the citizens' local knowledge about the landscape can be incorporated in the inventory phase of the environmental planning process [3]. Crowd sourcing of geo-referenced information about the local environment also generates more first-hand knowledge, which government officials often have little access to (ibid.). For this, special web tools have been developed over the last ten to fifteen years. Map-servers and WebGIS have made it possible to collect and present spatial data that is linked to environmental information, e.g., proposed planning measures or habitat information. Furthermore, spatial environmental data can also be linked to discussion threads in dialog forums or apps for smart phones in order to collect more visual, audio, or geo-referenced data, for example about elm trees (OpenElm) [6] or birds (Ardini) [7] in a specific habitat.

Thus, the use of the Internet in participation has moved from a static information flow in one direction (Web 1.0) to an interactive participatory approach of Web 2.0. User generated content is the key characteristic of Web 2.0 services. The change in the use of the Internet has led users to create, transform and share content using interactive applications [8]. Social media and web tools provide new opportunities to promote a new kind of knowledge creation by presenting and interacting with information in a larger social context, which has the potential to promote social learning [3]. More specifically, social networks are a relatively new communication mode in the web media development, and they hold much potential for accessing and incorporating citizens' opinions and suggestions. The network aspect changes the way people obtain informed about their special interests or current issues, for example, in their municipalities. In contrast to explicitly searching for information from a specific person or institutional source, in a social network a citizen can receive information as it happens only by networking with people who are involved in similar or related issues. Kanter and Fine call this "viral" communication [9]. However, such developments are not currently the state of the art in environmental planning. Although a dynamic participation process, in which users can interact with 
the information and create and discuss their own development scenarios, is a desirable goal, its integration into the formal administrative planning process remains difficult.

One goal of landscape planning is to generate information that supports the inclusion of environmental objectives in spatial decision-making. To reach this goal, decision makers must communicate sustainable development concepts to the public and stakeholders in a clear and understandable manner. Public involvement in the planning process serves as an essential opportunity to communicate the goals and objectives of sustainable planning. Furthermore, it is mandated by the Aahrus Convention [10] and European law $[11,12]$. However, environmental decisions are often based on expert knowledge and scientific content that can be difficult to communicate to lay audiences.

Linking environmental concepts with images and perceptions of sustainability that people are familiar with in their daily life is one way to communicate this information to lay groups. Research suggests that visualizations improve viewers' understanding of landscape change in that they communicated scientific information in a real world setting [13]. Visualizations can support meaningful discussion of the planning issues and can be an effective tool in planning [14]. Familiar landscapes and imagery of animals and people may also stimulate strong positive feelings among viewers, but they can also trigger emotional responses that upset people [15]. Realistic visualizations of future situations have a very powerful impact; however they are only simulations or "good guesses" about future planning solutions. Therefore, they must be created in a transparent and defensible manner [16]. Nevertheless, some 3D drama may help to reach viewers emotionally.

Beyond communicating information, it is important to incorporate the stakeholders' opinions, e.g., from landowners, and public knowledge about the landscape and environment in the planning decisions. In so doing planners and politicians have a better chance of enlisting public support, especially when the decision making process is transparent $[17,18]$. However, it is also necessary to understand how citizens view sustainable development of the environment on local or regional scale in order to anticipate where mistrust may lie. Today, people form their opinions, attitudes, and perceptions of environmental issues based, not only on information and commentaries in printed and online media, but also through face-to-face discussions and social media. Furthermore, people who are interested in ecological themes or movements often inform themselves about specific issues via the expansive information found on the Internet [19].

This article explores how sustainability concepts can be communicated to the public by using new communication opportunities in the Internet. Specifically, we examine landscape planning as an instrument that politicians and planners can use to promote sustainable environmental planning decisions. Furthermore, the article identifies opportunities that web tools and social media offer to improve communication between government authorities and citizens, and to promote public participation and transparency in the planning process. Using a framework for the use of social media, we suggest different application levels of social media in participatory planning. Finally, the opportunities to support sustainable decisions with landscape visualization in environmental planning and decisionmaking issues are discussed. 


\section{Sustainability as a Concept in Environmental Planning}

The concept of sustainability is used on different scales in many contexts with very different objectives. Climate activists attempt to change society's behavior on a global scale in order to establish a more sustainable way of living. Businesses promote their products with "green" images, and governments implement environmental protection legislation to ensure that natural resources will be used wisely and maintained for future generations. This paper focuses on the capability of landscape planning to promote sustainable solutions to spatial environmental issues.

At the local level, landscape planning functions as an instrument for sustainable development. It is comprehensive environmental planning that supports the multifunctionality of landscapes. In this context, it assesses the sustainability of existing and proposed land uses in relation to environmental capacity and landscape character [20]. Landscape planning addresses a wide range of landscape functions and the respective ecosystem services that the landscape provides humans, for example drinking water and flood protection. It is a governmental planning instrument which is committed to supporting public interests in the environment [21-24]. On one hand, it reflects societal values that are laid down in legislation, and, on the other hand, it regulates the interests of private landowners in order to ensure the public interest and the protection of natural resources. Larger issues of sustainability, such as the interests of future generations or supra-local societal needs, must be considered in landscape planning, although they may conflict with the short-term, local demands of stakeholders [25]. However, it is essential that decision makers communicate decisions about such conflicts of interests in a transparent and understandable manner to citizens and stakeholders in order to gather citizen support for sustainable environmental decisions.

\subsection{Perceptions and Attitudes towards Sustainability on the Local Scale}

To be effective, planners must understand what sustainability means to citizens with respect to local environmental issues and how these perceptions can be accommodated through landscape planning. Using a case study approach, we investigated citizens' perception of sustainability on the local scale by examining citizens' responses to the development of intensive livestock farming in a rural setting. A qualitative study of a citizens' protest initiative who opposed the project to limit mass livestock farming in a rural area of Lower Saxony, Germany, was used to identify some perceptions of sustainability in the context of proposed development with negative environmental effects. Interviews were carried out with engaged citizens who held different formal functions in the citizens' protest initiative: chairwoman, people responsible for (membership) campaigns, local politician of the Green party, and members of the initiative.

The statement of one of the activists exemplifies the findings of the investigation. In an interview, the activist, who we will name Doris, described her general attitude toward intensive livestock farming and what motivated her to become involved in the opposition. Doris had lived in the area for thirty years and was well-acquainted with the visible environmental conditions of the landscape as she had frequently ridden her horse through the forests and fields. She recognized the fact that the water level of the area had progressively declined over the last few decades. However, this knowledge did not motivate her to become active in environmental issues, possibly because it occurred slowly over many 
years. However, she became alarmed about environmental concerns when the plan to build a slaughter house was unexpectedly published in the local newspapers and she heard information about environmental impacts of mass livestock farming:

"Yes, and then I heard about the slaughter house that was planned for here. I thought-I rode there often in former times, what everyone did here. You see a lot of the landscape out there. I considered that a slaughter house will be built here, that can't be true, and almost the biggest in Europe. Hmm. Then I went to the town council and heard that everyone was for it! [...] That all happened in a very short period. Seeing the plan makes you wonder. In 2009 we had grassland there, at that time it was really all grassland without anything else. That was really surprisingly to me. Then I realized that over the many years of riding out there, there has been the large water works in F. (anonymized village), which pumped all the water to H. (anonymized city), and the water level declined a lot. You can see it out there, where in former times-I live here thirty years-water existed, now it is no longer there. Now trees cover the whole area, it has simply become a forest, and you don't realize it when it happens. But the water level has declined significantly. It's because of the sandy ground here, the rain runs through it and disappears... And now I read that this slaughter house needs nine liters of fresh water for each animal. Then I thought okay, we do not need it here at all. It outraged me. I am not really a friend of animal protection, although it scares me what happens to the animals there, but it was not my first reason." (Doris).

She became involved in the citizens' protest initiative, which grew very quickly after the plan was publicized. There, she received information about the environmental impacts of the proposed plan. The fact that slaughter houses use large amounts of fresh water (in this case circa nine liters for each animal and round about 40,000 animals slaughtered per day) was critical information for her, which she could combine with her knowledge about the declining water level in the area that she had observed. Furthermore, information about the transportation of the animals and the meat caused her even more concern:

"Then I thought, okay, it has a bigger dimension. The animals have to be brought here; the meat has to be carried away from here. A lot is related to this. [...] And then the company owner introduced himself and said this county is a "favored area" for mass livestock farming. I could not get the term "favored area" out of my mind." (Doris).

This apprehension motivated her to become involved in the citizens' protest initiative and stimulated her to find out more about the relationship between mass livestock farming and environmental impacts as well as its sustainability.

\subsection{Discussion of Case Study Results}

Although the case study deals with the impacts of mass livestock farming, its relevance lies in the examination of the citizens' perception of sustainability issues on local and regional scale in their daily lives. In Doris' example, her awareness of sustainability issues started at the local scale when she recognized the declined of the water level on her rides through the landscape. This illustrates how aspects of sustainability become relevant for citizens when they touch their everyday lives and 
experience on local or regional scale. The environmental impacts of a proposed land use must not impinge on the societal demands for the wellbeing of the local citizens, for example, their need for adequate unpolluted water and air as well as a healthy landscape. Furthermore, the administration and government must purse decisions about local sustainability that balance the interests of nature conversation, on one hand, and the economic goals of land owners on the other. Sustainability concepts not only apply to environmental decisions but also to economic goals such as efficiency (efficient use of resources), consistence (sustainable trade flows of resources), and sufficiency (a sustainable prosperity model) [26].

When societal demands of sustainable wellbeing are not considered sufficiently or the decisions are not communicated in a transparent manner, then planning issues and decisions can meet resistance. For example, the awareness about the environmental impact of intensive livestock farming, which was raised by the citizens' protest initiative, caused the public to question the sustainability of the local planning decisions. The lack of transparency of the planning and decision-making process, as well as the lack of openness about important information, led to distrust among the citizens. Distrust often fosters conflicts in decision-making and inhibits collaborative participation of local citizens.

If citizen awareness and interest about sustainability issues are triggered by personal experience or attachment to the landscape, and trust in the decisions made by local governments is improved with access to information and transparent decision processes, then the Internet holds great potential to improve trust and satisfaction about the sustainability of local planning decision. However, the question remains whether improved communication and access to information about environmental protection found on the Internet and social media increases the public's awareness of sustainability.

\section{Communication about Sustainability on the Local Scale}

Facing the environmental challenges of the future requires that we address environmental problems at the local and regional scale in a way that improves human and environmental interrelations and supports collective action and social change [27]. A prerequisite for this is public interest and awareness for nature and the landscape. Therefore, the first step of communicating sustainability is to draw attention to the changes that are occurring in the natural landscape. This step must be promoted by governmental authorities when they communicate with citizens or non-governmental agencies that promote nature conversation.

The second step to improving human and environmental interrelations is to encourage social learning about sustainability and the avoidance of environmental impacts. Social learning goes beyond the individual learning processes (for a review of definitions see [28]) and enables us to learn as a society. Social learning can also have a spontaneous character [29], but ultimately it should enhance the capacity of citizens to understand how social-ecologic systems cope with challenges associated with sustainability [30,31]. In other words, the aim is to create learning experiences in which the connections between our actions/behavior and environment become clear and can lead to social change. Such learning experiences are often affected by communication processes.

Kanter and Fine contend that web communication tools, such as social media, are able to directly influence social interest in specific issues [9]. In an attempt to better understand the first step of 
communicating sustainability, we used a small case study to investigate whether modern web 2.0 services, in our case Facebook, could improve interest in environmental planning measures.

\subsection{Using Social Media to Communicate between Government and Public and between Public Actors in Institutionalized Planning Processes}

Opportunities to use social networks for environmental planning were tested in the context of the re-evaluation of the Interactive Landscape Plan in Königslutter am Elm (IALP), Germany (project sponsored by the German Federal Agency for Nature Conservation). The research team posted information and photos about an environmental planning measure in a citizen's discussion group about Königslutter on Facebook. The post included two photos and a description of the renaturalization of Rottorf's village pond in Königslutter, which was proposed in the IALP and implemented in 2006 (see Figure 1). The plan restored native vegetation and one shore was developed as a bird refuge. The post was made under the name "research team environmental planning Hannover" (Forschungsteam Umweltplanung Hannover) and information about our relationship to the city and involvement in the particular measure were also posted. Facebook group members were invited to respond to two questions about the planning measure: Do you know about the measure? Did you use the pond after renaturalization? The post was followed for four days.

Figure 1. Posted information and photos about an environmental planning measure in a citizen's discussion group about Königslutter in Facebook.

Forschungsteam Umweltplanung Hannover

Ihre Meinung ist uns wichtig! Wir sind ein Forschungsteam der Universität Hannover, das von 2002-2005 den interaktiven Landschaftsplan in Königslutter begleitet hat. Heute würden wir gerne etwas über den Bekanntheitsgrad der damals umgesetzten Maßnahmen in der Landschaft erfahren.

Der Dorfteich Rottorf, der an der Landesstraße 644 und Kreisstraße 9 liegt, wurde 2006 im Rahmen dieses Landschaftsplans für Mensch und Tier umgestaltet. Ost- und Südufer wurden abgeflacht und die Pappeln gefällt, damit andere einheimische Gehölze sich ausbreiten konnten. Das Westufer wurde als beruhigtes Brut- und Rückzugsgebiet für Vögel entwickelt. Durch einen Graben sollte dieser

Bereich vor dem Betreten geschützt werden. Die Bilder zeigen das Südufer einmal vor dem Abflachen und einmal nach den Umbaumaßnahmen.

Nun sind sieben Jahre vergangen. Unsere Fragen sind:

1. Ist Ihnen diese Umgestaltung bekannt?

2. Haben Sie den Teich nach der Umgestaltung genutzt?

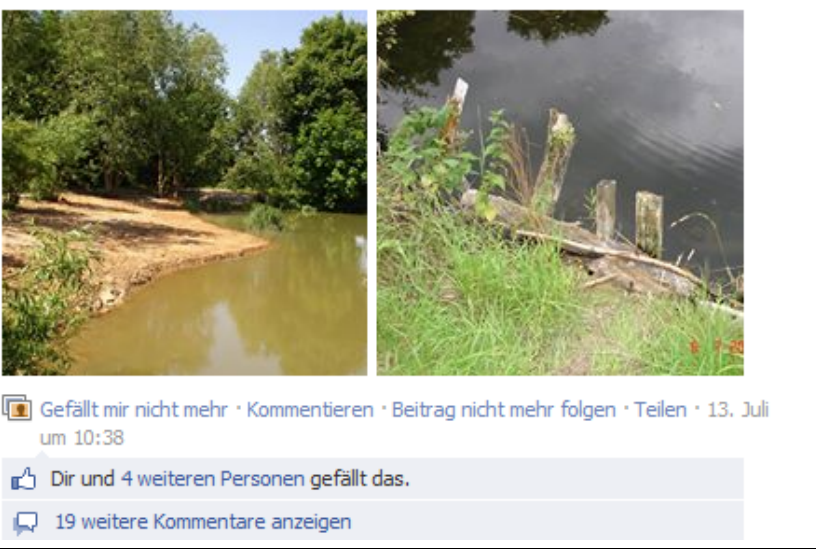


Thirteen people responded to the questions with 19 comments. [Initially, this seems to be very little response, but it should be noted that approximately ten to thirty posts are placed every day (many with more than one photo) and most of the group members do not respond. Furthermore, the issue is very specific and there is limited interest, even in a small city like Königslutter with $c a$. 15,500 inhabitants.] Chronologically, the first comment was a statement from a member of a non-governmental agency for nature conversation, who complained that his agency had only limited involvement in the landscape planning measure management since the end of the project in 2006. The author of the second comment rated the Internet platform of the IALP as outdated in terms of map functionality and other technical issues, rather than rating the presented measure. The third post asked for the location of the pond. The author of the second post responded with information about where to find the Interactive Landscape Plan platform, but not where to find the pond. The fifth comment was an answer to our two questions, both "no", but the author knew where the pond was located (but did not explain it). The sixth comment rated the photos and answered our questions both with "no". The seventh comment rated the measure itself as "very nice" as she knew the measure, but did not want to use the pond for swimming. This statement introduced swimming as a potential use of the pond to the discussion. The next user asked where to find the pond again. However the following user only said she knew the pond because she goes for a walk there sometimes but did not go swimming.

Summarizing this portion of the discussion, the users' posts expressed their opinions and questions related to the IALP, but they did not necessarily focus on the questions asked by the researchers. Furthermore, the users did not directly answer the questions from other users about the location of the pond. In other words, they posted their opinions, but did not join in a group discussion. Finally the new topic of swimming in the pond was picked up by the participants and initiated the following discussion.

The next comment rated the measure as "looking great", but also asked if it was dangerous to swim there. The following comment explained that the pond is personally known but advised against swimming there. Then, the former question about the location of the pond was repeated by the same user and it was then answered clearly. The next comment answered both of our questions with "no", but mentioned a new aspect. He questioned whether the public could use the pond. This new consideration prompted a statement about a fence and gate around the pond, which made the user question if the pond was public and if swimming was allowed. She became aware of the building activities only a few years prior. The author introduced the idea that mud and dead wood at the bottom of the pond made swimming dangerous. She also mentioned some other uses such as skating in the winter, if the pond freezes. Apart from the dangers for swimmers, she likes the measure very much.

In summary, three comments not only answered the questions but also expressed their satisfaction about the planning measure. One proposed additional ideas for further development of the pond. Three people shared new information about using the pond and five people asked questions about the use of the pond, for example swimming, and three people answered the questions posed by others in the group. The format allowed citizens and local experts to answer questions using their local knowledge, without involving city or planning administrators.

The open dialog format enables these kinds of communication in contrast to a one-way information exchange, such as a simple poll, that would not support the creation of additional, and perhaps unexpected, content for the public. Also the administration could offer additional information in 
response to special questions or proposals made in the comments. For example, the researchers responded in the last post that the pond was not an official swimming area.

Our research goals for the test post were to investigate how a Facebook group can be used to promote a particular landscape planning measure, raise awareness about the environmental program and share content to activate participants' interest. The question remains how interactive web tools and social media can support communication processes in order to promote environmentally sustainable behavior and planning decisions. To analyze the benefit of such a communication approach for government and administration, we must evaluate the potential use of social media in more detail. Social media can be used in different intensities and with a variety of objectives in the participatory planning process. Table 1 shows the different levels of participatory involvement with social media and network tools as well as a variety of programs and web-based tools that are available to support these objectives and the various planning tasks.

Table 1. Overview of levels of participation in social media (Adapted from Beth Kanter [32]).

\begin{tabular}{|c|c|c|c|c|c|}
\hline & Listen & Promote & Participate & Share content & Build community \\
\hline Objectives & $\begin{array}{l}\text { Know what is said } \\
\text { online about } \\
\text { environmental } \\
\text { issues }\end{array}$ & $\begin{array}{l}\text { Raise awareness } \\
\text { of environmental } \\
\text { planning } \\
\text { programs, } \\
\text { opportunities, } \\
\text { planning } \\
\text { activities }\end{array}$ & $\begin{array}{l}\text { Join a } \\
\text { conversation } \\
\text { with citizens } \\
\text { about } \\
\text { sustainability/env } \\
\text { ironmental } \\
\text { measures }\end{array}$ & $\begin{array}{l}\text { Share information } \\
\text { or results of } \\
\text { environmental } \\
\text { measures }\end{array}$ & $\begin{array}{l}\text { Build relationships } \\
\text { online, nurture } \\
\text { community, engage } \\
\text { people, encourage } \\
\text { them to take action } \\
\text { or adapt sustainable } \\
\text { life style }\end{array}$ \\
\hline $\begin{array}{l}\text { Technical } \\
\text { possibilities }\end{array}$ & $\begin{array}{l}\text { Google Alerts, } \\
\text { Twitter, } \\
\text { Socialmention, and } \\
\text { RSS readers, etc. }\end{array}$ & $\begin{array}{l}\text { Twitter, Share } \\
\text { This, and Digg, } \\
\text { etc. }\end{array}$ & $\begin{array}{l}\text { Facebook, } \\
\text { Twitter and } \\
\text { LinkedIn etc., } \\
\text { encourage } \\
\text { bloggers to } \\
\text { write about } \\
\text { environmental } \\
\text { issues }\end{array}$ & $\begin{array}{l}\text { Blogging, } \\
\text { podcasts, You } \\
\text { Tube, video } \\
\text { sharing sites, } \\
\text { Flickr, etc. }\end{array}$ & $\begin{array}{l}\text { Ning, LinkedIn, etc. } \\
\text { for knowledge } \\
\text { and skill sharing } \\
\text { Facebook, MySpace, } \\
\text { etc., to engage new } \\
\text { supporters }\end{array}$ \\
\hline $\begin{array}{l}\text { Tasks/Skills } \\
\text { needed }\end{array}$ & $\begin{array}{l}\text { Pattern analysis } \\
\text { (Link listening and } \\
\text { analysis to } \\
\text { decisions or } \\
\text { actions) }\end{array}$ & $\begin{array}{l}\text { Build trust, } \\
\text { credibility and a } \\
\text { relationship with } \\
\text { interested } \\
\text { participants }\end{array}$ & $\begin{array}{l}\text { Participatory } \\
\text { competencies } \\
\text { like listening, } \\
\text { interpreting, } \\
\text { opinion sharing } \\
\text { skills }\end{array}$ & $\begin{array}{l}\text { Create content } \\
\text { and use buzz tools } \\
\text { to share. Goal is } \\
\text { to motivate others } \\
\text { to share their } \\
\text { information/ideas } \\
\text { about the issues }\end{array}$ & $\begin{array}{l}\text { Engage participants } \\
\text { to reach out to their } \\
\text { personal social } \\
\text { networks, create } \\
\text { their own content, or } \\
\text { activities to share }\end{array}$ \\
\hline $\begin{array}{l}\text { Level of } \\
\text { involvement }\end{array}$ & $\begin{array}{l}\text { Passive } \\
\text { Engagement }\end{array}$ & Broadcast/Share & Low Engagement & Content intensive & High Engagement \\
\hline
\end{tabular}

Using the levels of participation in social media suggested in Table 1, we analyzed the use of a social network for environmental communication in our test post. Prior to the post, we observed the Facebook group to determine what kinds of topics were being discussed. After broadcasting our information as a post (promote), we were able to determine awareness, interest, and attitudes about the planning measure simply through passive observation. And this communication could also be a benefit 
for administration to promote their activities for nature conservation and quality of well-being. In response, the non-governmental participants in the group began to participate by answering our questions and commenting on the measure. Some participants even shared content about the topic by posting links to special contextual information or by answering questions of other participants. They discussed different possibilities to use the pond and, for some, it was new that the pond was public. It is possible that through the linked information or answers to their question, the participants learned something about environmental measures that protect a natural biotope and how such a renaturalization could benefit, both, nature and human use. Information about the increased environmental knowledge of the participants was not gathered during the test. However, some participants did learn about the location and possibilities to use the pond for the first time.

We were not able to build a community during the test because the time frame was too short. Generally three to six months are needed to build a social community [32]. However, social relationships established during the interactive landscape planning process from 2002-2005 were transferred into the cyber network when a former stakeholder in the planning process posted his comments.

Examples, such as this communication test using Facebook show that civil actors in social networks answer questions or provide additional information to each other, often much faster than waiting for answers from institutional actors. In addition, these statements from non-governmental sources often contain more details or local knowledge, special hints or alternative opinions/interpretations of particular issues. Furthermore, social networking reduces the amount of time people need to obtain an overview of many issues; however the information may also be more cursory. This is related to the way people connect in social networks. People who actively use social networks beyond their immediate family and personal friends tend to form looser ties with others in the network. "Strong ties are the relationships you have with close personal friends or relatives. Loose ties are lighter connections that friendly acquaintances have with one another" [9]. These loose ties are powerful for sharing information because they spread it in a wide radius ("viral"). However, maintaining an overview of the individual ties becomes more extensive and cursory within a limited time frame.

The social network holds opportunities for the planning administration in Königslutter to find out about new ideas and wishes of the citizens as well as their opinions about proposed and implemented planning measures. As an observer in social networks, governments, or administrations can inform themselves about the issues that citizens consider important. Social networks also allow governments to inform a large number of citizens about sustainability and environmental issues with relative little effort.

\subsection{Visualization in Planning Processes on Local or Regional Scale}

Visualization is also a means of communicating the message about sustainability to stakeholders, politicians, and citizens. It not only helps engage people's interest in the issues, it can also help to inform and educate as well as encourage people to change their lifestyle [15]. A visualization provides a common language for discussion that everyone can understand. It may even stimulate people to ask questions they had not thought about or to think about the issues in different ways [33].

Visualizations of the landscape are a powerful means to connect citizens to their personal landscape at the local scale, which is the first step of communicating sustainability. Realistic, detailed visualizations, 
such as panorama photos or even aerial photographs, enable viewers to easily recognize their landscape, and they offer opportunities for citizens to impart their experience and knowledge about the landscape [3]. Next, citizens must understand how proposed planning measures will influence their landscape in order to form opinions about the sustainability of those changes. Visualizations, such as photomontage, renderings, or even sketches, which allow viewers to compare the "before and after" states of proposed landscape change, are essential in the discussion of sustainable change to the landscape and environmental impact [34]. Such simulations, although only predictions of a future state, help the public picture and compare the possible visual impacts of planning proposals. Finally, visualizations that enable people to interactively develop their own ideas represent an ideal opportunity for users to explore their ideal of sustainable development. For example, citizens in Königslutter collaboratively developed a photomontage of their proposal for improving a meadow habitat (see Figure 2). Interactive visualization methods that allow stakeholders to develop their own scenarios and alternative futures, such as CommunityViz ${ }^{\circledR}$ [35], provide an opportunity, not only to explore sustainable alternatives and to develop collaborative solutions, but also to foster social learning.

Figure 2. Workshop participants develop a proposal for improving a meadow habitat.

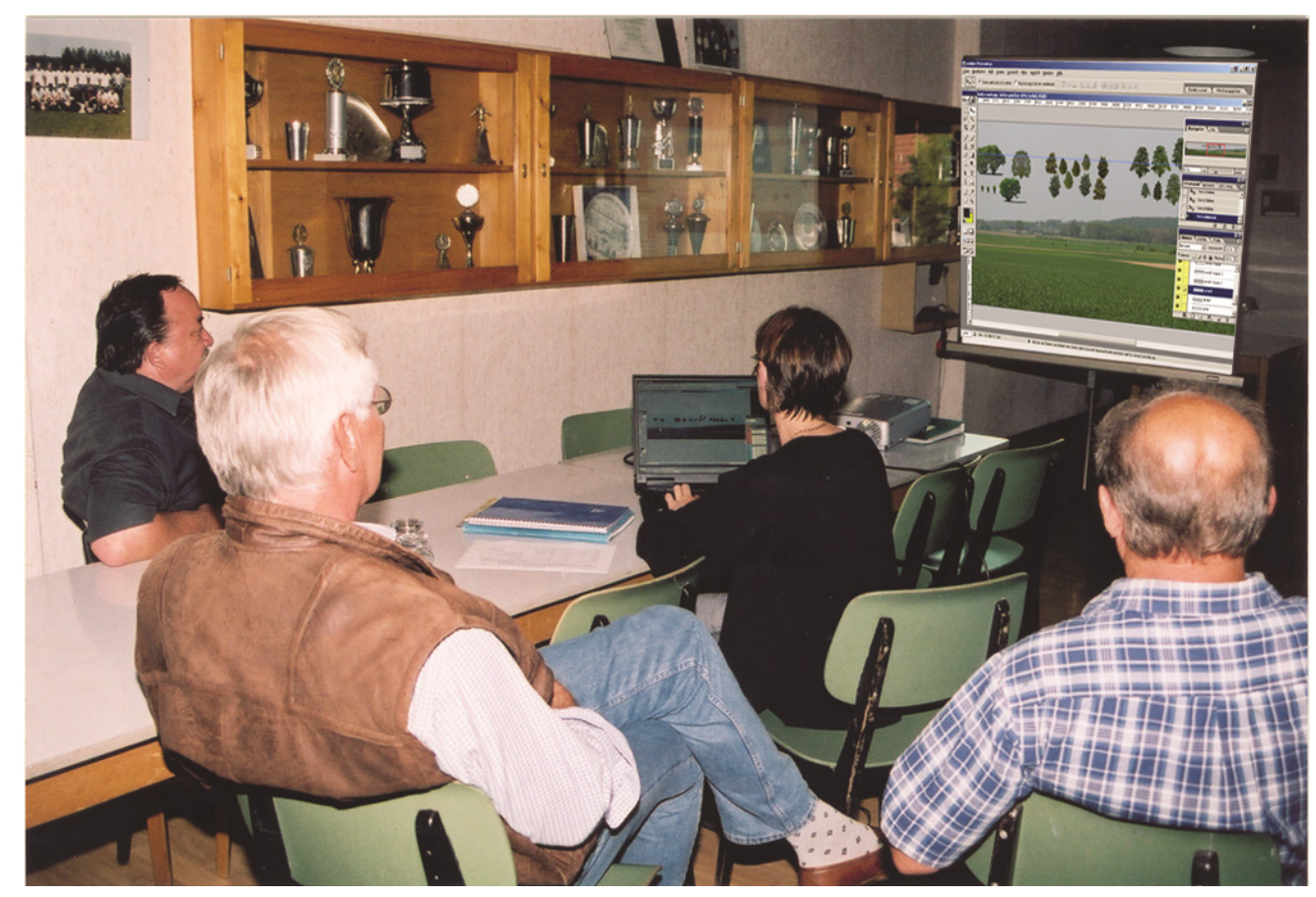

Even when people are aware of sustainability issues, they may not be willing to act or change their behavior. Sheppard [36] argues that: visualization may help to accelerate social learning and behavioral change in particular by bringing sustainability home to people in their back yard: for example, "making climate change personal". The advantages of visualization go beyond cognitive understanding of the effects of development on the landscape. It can illicit an emotional response to environmental issues and may even motivate decision makers to implement change [37]. Planning authorities need to recognize that visualizations can be a valuable tool for communicating and discussing proposed change, and that they also have the capacity to stimulate a personal and often emotional response to sustainability issues. 


\section{Conclusions}

Social networks can provide different kinds and levels of information that are important to planners. For informal participation in planning, authorities can use social networks, such as Facebook, to:

- Follow current topics that concern the public,

- Collect local knowledge about the existing state of the landscape,

- Gather opinions and rate planning alternatives as well as,

- Promote an exchange of information about the local landscape among concerned citizens.

The ultimate goal is to build a community of citizens who actively promote environmental awareness and a sustainable lifestyle by supporting sound environmental decisions.

New approaches in interactive web tools, social media and new kinds of end devices like smart phones provide new opportunities for planning administrations to crowd source information and collect local knowledge that is valuable for informed environmental planning decision. Furthermore, such networks can help the public to learn more about the local environmental issues and thus be able to make a more informed opinion about sustainable planning decisions.

Our case study of Facebook showed that people who were familiar with the specific planning measure were satisfied with the results. However many people were not informed about the issue. In the future, the administration in Königslutter could use this Facebook group to improve transparency about existing ecosystem services and to publicize information about new planning measures and the monitoring of implemented environmental measures. Finally, special social network monitoring applications, e.g., Google Analytics or Twazzup for Twitter, offer town administrators the opportunity to analyze which themes are en vogues in social networks and how information is distributed. Such analyses hold the potential to identify important stakeholders and actors in the participatory process.

In addition, landscape visualizations have the potential to support not only understanding of landscape issues, but they also help citizens to identify emotionally with local planning measures and their landscape. Such an emotional connection has been shown to influence behavior. These new approaches to participation can improve the involvement of citizens in the planning process and help access local knowledge while encouraging citizens to take part in the discussion about sustainability in their community. They also offer local experts the opportunity to give qualified answers to many questions that the public may have, and in this way, relieve the planning administration of routine inquiries.

When factual discussions about environmental issues occur in social networks, they have the potential to support social learning about environmental issues especially on local or region scale among the participants. They could be an impetus not only for sustainable development of the existing natural resources but also for a change in awareness and attitude about sustainable development on local or region scale and ultimately alter behavior. In the context of environmental planning, social learning can occur among people who are involved in environmental issues but also between governmental organizations and the general public. In contrast to top-down planning approaches, social learning reflects the idea that the shared learning of interdependent stakeholders is a key mechanism for arriving at more desirable solutions that enhance, for example, ecological sustainability [38]. Interactive or participatory problem solving is central to social learning. This involves collaboration between 
different stakeholders early in the process in order to build trust and a common view on the issues and later to resolve conflicts and develop joint solutions.

In open government, the Internet and social media offer opportunities to enhance communication during the planning and decision-making processes. However, the limitations of their use in the formal planning process must also be recognized, especially in their practical application. When communicating, it is important to consider the objective and the modus of a dialog. Dialogue tools are most suitable for deliberative processes; however, formal participatory processes require moderation. The goals and limitations of discussions must be clearly defined in order not to raise expectations that cannot be fulfilled. For example, landscape planning is a formal process that is bound to environmental protection legislation. Therefore, legal requirements must be fulfilled and are not subject for discussion. Public commentary functions are recommended only if they can be evaluated within the planning process and a summary is sufficient feedback. Similarly, landscape visualization and interactive maps offer clear benefits in the participatory process, e.g., visualized planning alternatives. Although such communication tools require more expense and know-how, they can generate transparency, public interest, acceptance, and possibly social learning about complex issues of sustainable development.

\section{Acknowledgments}

We acknowledge support by Deutsche Forschungsgemeinschaft and Open Access Publishing Fund of Leibniz Universität Hannover.

\section{Conflicts of Interest}

The authors declare no conflict of interest.

\section{References}

1. Barnes, S.H.; Kaase, M. Political Action: Mass Participation in Five Western Democracies; Sage: Beverly Hills, LA, USA, 1979.

2. Vester, M. Auf Dem Weg zu Einem, Partizipatorischen Wohlfahrtsstaat“? Vom Informationstechnologisch-Neoliberalen zu Einem Ökotechnologisch-Sozialen Entwicklungspfad. In Zukunft der Demokratie-Demokratie der Zukunft (in German); Birsl, U., Schley, C., Wilke, P., Eds.; Friedrich-Ebert-Stiftung Landesbüro Niedersachsen: Hannover, Germany, 2011; pp. 135-168.

3. Haaren, C.V.; Oppermann, B.; Friese, K.-I.; Hachmann, R.; Meiforth, J.; Neumann, A.; Tiedtke, S.; Warren-Kretzschmar, B.; Wolter, F.-E. Interaktiver Landschaftsplan Königslutter am Elm: Ergebnisse aus dem E+E-Vorhaben "Interaktiver Landschaftsplan Königslutter am Elm” des Bundesamtes für Naturschutz (in German); Bundesamt für Naturschutz: Bonn-Bad Godesberg, Germany, 2005.

4. Mitterhuber, R. Social Media und öffentliche Verwaltung: Wie weit darf man gehen? (in German). Available online: http://www.nlt.de/pics/medien/1_1347024746/Social_Media_und_ oeffentliche_Verwaltung_-_Wie_weit_darf_man_gehen.pdf (accessed on 29 July 2013).

5. Bamberg, J. Engaging the public with online discussion and spatial annotations: The generation and transformation of public knowledge. Plan. Theory Prac. 2013, 14, 39-56. 
6. Artenerfassung digital in Niedersachsen (in German). Available online: www.ardini.de (accessed on 15 October 2013).

7. Open elm project. Available online: www.openelm.org.im (accessed on 15 October 2013).

8. Paeßler, B. Social Media für Initiativen und Vereine (in German); Social Media für Initiativen und Vereine: Mühlheim/Ruhr, Germany, 2013.

9. Kanter, B.; Fine, A.H. The Networked Nonprofit: Connecting with Social Media to Drive Change; Jossey-Bass: San Francisco, CA, USA, 2010.

10. The Aarhus Convention: What is the Aarhus Convention? Available online: http://ec.europa.eu/ environment/aarhus/ (accessed on 8 November 2013).

11. Directive 2003/4/EC of the European Parliament and of the Council of 28 January 2003 on Public Access to Environmental Information and Repealing Council Directive 90/313/EEC. Available online: http://eur-lex.europa.eu/LexUriServ/LexUriServ.do?uri=CELEX:32003L0004:EN:HTML (accessed on 8 November 2013).

12. Directive 2003/35/EC of the European Parliament and of the Council of 26 May 2003 providing for public participation in respect of the drawing up of certain plans and programmes relating to the environment and amending with regard to public participation and access to justice Council Directives 85/337/EEC and 96/61/EC-Statement by the Commission. Available online: http://eurlex.europa.eu/LexUriServ/LexUriServ.do?uri=CELEX:32003L0035:EN:HTML (accessed on 8 November 2013).

13. Schroth, O. From Information to Participation: Interactive Landscape Visualization as a Tool for Collaborative Planning; vdf Hochschulverlag ETH Zürich: Zürich, Switzerland, 2010.

14. Salter, J.D.; Campbell, C.; Journeay, M.; Sheppard, S.R.J. The digital workshop: Exploring the use of interactive and immersive visualisation tools in participatory planning. J. Environ. Manag. 2009, 90, 2090-2101.

15. Nicholson-Cole, S.A. Representing climate change futures: A critique on the use of images for visual communication. Comput. Environ. Urban Syst. 2005, 29, 255-273.

16. Sheppard, S.R.J. Visualizing Climate Change: A Guide to Visual Communication of Climate Change and Developing Local Solutions; Routledge: London, UK, 2012.

17. Bachmann, J.; Hage, G. Leitfaden für die kommunale Landschaftsplanung in Baden-Württemberg (in German). Available online: http://www.lubw.baden-wuerttemberg.de/servlet/is/41319/ Landschaftsplan_im_Detail.pdf?command=downloadContent\&filename=Landschaftsplan_im_De tail.pdf (accessed on 29 July 2013).

18. Luz, F. Participatory landscape ecology-A basis for acceptance and implementation. Landsc. Urban Plan. 2000, 50, 157-166.

19. Manila, A. Perspectives on Citizen Democratisation and Alienation in the Virtual Public Sphere. In Digital Democracy: Discourse and Decision Making in the Information Age; Hague, B.N., Loader, B.D., Eds.; Routledge: London, UK, 1999; pp. 23-38.

20. Haaren, C.V.; Warren-Kretzschmar, B. The interactive landscape plan: Use and benefits of new technologies in landscape planning and discussion of the interactive landscape plan in Koenigslutter am Elm, Germany. Landsc. Res. 2006, 31, 83-105.

21. Council of Europe. European Landscape Convention; Council of Europe: Florence, Italy, 2000.

22. Olschowy, G. The development of landscape planning in Germany. Landsc. Plan. 1976, 3, 391-411. 
23. Faludi, A. A decision-centred view of environmental planning. Landsc. Plan. 1985, 12, 239-256.

24. Runge, K. Entwicklungstendenzen der Landschaftsplanung: Vom Frühen Naturschutz bis zur Ökologisch Nachhaltigen Flächennutzung (in German); Springer: Berlin, Germany, 1998.

25. Haaren, C.V.; Albert, C. Integrating ecosystem services and environmental planning: Limitations and synergies. Int. J. Biodivers. Sci. Ecosyst. Serv. Manag. 2011, 7, 150-167.

26. Kleinhückelkotten, S. Suffizienz und Lebensstile. Ansätze für Eine Milieuorientierte Nachhaltigkeitskommunikation (in German); Berliner Wissenschafts-Verlag: Berlin, Germany, 2005.

27. Keen, M.; Brown, V.; Dyball, R. Social Learning in Environmental Management: Towards a Sustainable Future; Earthscan: London, UK, 2005.

28. Albert, C.; Zimmermann, T.; Knieling, J.; Haaren, C.V. Social learning can benefit decision-making in landscape planning: Gartow case study on climate change adaptation, Elbe valley biosphere reserve. Landsc. Urban Plan. 2012, 105, 347-360.

29. ADAM ADaptation And Mitigation Strategies: supporting European climate policy. Available online: http://www.tyndall.ac.uk/adamproject/about (accessed on 19 December 2013).

30. Folke, C.; Colding, J.; Berkes, F. Synthesis: Building Resilience and Adaptive Capacity in Social-Ecological Systems. In Navigating Social-Ecological Systems: Building Resilience for Complexity and Change; Berkes, F., Colding J., Folke, C., Eds.; Cambridge University Press: Cambridge, UK, 2003; pp. 352-387.

31. Tompkins, E.; Adger, W.N. Does adaptive management of natural resources enhance resilience to climate change? Ecol. Soc. 2004, 9, 10.

32. Beth's Blog: Nonprofits and Social Media. Available online: http://beth.typepad.com/beths blog/2008/10/how-much-time-d.html (accessed on 25 July 2013).

33. Meitner, M.J.; Sheppard, S.R.J.; Cavens, D.; Gandy, R.; Picard, P.; Harshaw, H.; Harrison, D. The multiple roles of environmental data visualization in evaluating alternative forest management strategies. Comput. Electron. Agric. 2005, 49, 192-205.

34. Warren-Kretzschmar, B. Visualization of Landscape Planning-Choosing Appropriate Visualization Methods for Public Participation; Dissertation Leibniz University: Hannover, Germany, 2011.

35. CommunityViz. Available online: http://placeways.com/communityviz (accessed on 17 November 2013).

36. Sheppard, S.R.J. Bridging the sustainability gap with landscape visualisation in community visioning hubs. Integr. Assess. J. 2006, 6, 79-108.

37. Sheppard, S.R.J.; Cizek, P. The ethics of Google Earth: Crossing thresholds from spatial data to landscape visualisation. J. Environ. Manag. 2009, 90, 2102-2117.

38. Leeuwis, C.; Pyburn, R. Social Learning for Rural Resource Management. In Wheelbarrows Full Of Frogs: Social Learning in Rural Resource Management: International Research and Reflections; Leeuwis, C., Pyburn, R., Eds.; Koninklijke Van Gorcum: Assen, The Netherlands, 2002; pp. 11-24.

(C) 2014 by the authors; licensee MDPI, Basel, Switzerland. This article is an open access article distributed under the terms and conditions of the Creative Commons Attribution license (http://creativecommons.org/licenses/by/3.0/). 